\title{
A Delicate Balance: Re Charkaoui and the Constitutional Dimensions of Disclosure
}

\section{Graham Hudson*}

\section{Introduction}

In the wake of 9/11, Canada quickly adopted a wide range of new criminal law provisions designed to more effectively prevent and punish transnational terrorist activity. ${ }^{1}$ Despite the availability of these measures, counter-terrorism policy has since been pursued primarily through immigration law. This is in some ways unsurprising. While transnational terrorist activities span jurisdictions, the jurisdictions of law-enforcement agencies are generally domestically bounded, limiting their independent ability to launch effective investigations and prosecutions. Immigration law helps coordinate Canadian, foreign, and international counter-terrorism strategies by facilitating the movement of alleged terrorists to jurisdictions where they may be prosecuted more effectively or more conveniently. From the government's standpoint, an added advantage is that evidentiary burdens and standards of proof are far lower in deportation proceedings than in criminal proceedings, making it easier to reduce the threats that some non-citizens may pose to $\mathrm{Ca}$ nadian national security.

Unsurprising as it may be, the use of immigration law to perform criminal-law functions raises serious questions about the extent to which constitutional principles germane to the criminal process should be applied to immigration. Security certificates are perhaps the most conspicuous instrument to raise these questions. ${ }^{2}$ First enacted in 1976, security certificate legislation allows the government to target non-citizens in Canada who are alleged, among other things, to pose a serious risk to national security. Individuals who are subject to security certificates ("named persons") are arrested and detained. If their certificates are found by reviewing judges to be reasonable, they are deported. Although they may be detained for several years and then deported to face criminal or military trials, as well as the serious risk of human-rights abuses, named persons are denied the protection of basic criminal law principles. In particular, they are prevented from accessing much of the evidence used against them, denied full rights of appeal, and altogether excluded from hearings that concern classified information and other evidence.

Despite the courts' reluctance to strike down or modify certificate legislation, ${ }^{3}$ they have begun refining the system to better reflect criminal law principles. In 2007, the Supreme Court of Canada decided in Charkaoui $I^{4}$ that certificate proceedings are analogous to criminal proceedings and that persons named in security certificates consequently have a constitutional right to a fair hearing, including adequate levels of disclosure, fairness, and adversarial challenge. In 2008, the government complied with this judgment by integrating a special advocate system into the Immigration and Refugee Protection Act (IRPA), providing detainees with legal representation during secret hearings. ${ }^{5}$ Shortly after this amendment, the Supreme Court again relied on criminal law principles in Charkaoui II,${ }^{6}$ ruling that the government must retain and disclose to reviewing judges and spe- 
cial advocates all information on file relevant to named persons.

These expanded disclosure obligations reflect criminal law standards without replicating them in security certificate proceedings. Nonetheless, expanded disclosure has greatly improved the ability of named persons to defend themselves. In fact, in October 2009, Mr. Adil Charkaoui secured his unconditional release following a dispute over disclosure in $R e$ Charkaoui. ${ }^{7}$ The dispute began when a Federal Court judge ordered the government to disclose information to Mr. Charkaoui that the government insisted could not be safely released. Unwilling to comply with this order, the government withdrew the evidence, leaving so little on file that the certificate against Mr. Charkaoui was rendered factually unsupportable. The government hoped that this dramatic move would force an appeal on the criteria used by reviewing judges when deciding about matters of disclosure - criteria it felt had been improperly derived from criminal-law jurisprudence. This strategy backfired. The reviewing judge found the certificate to be illegal, quashed it, and ruled that relevant statutory provisions barred the certification of the government's questions for appeal.

Viewed in its broader constitutional context, Re Charkaoui shows how the judiciary, the executive, and Parliament have struggled to balance values of national security and human rights in certificate proceedings. On the one hand, courts have recognized the quasicriminal nature of certificate proceedings and applied criminal-law principles in this context. On the other hand, and despite the symbolic force of Charkaoui I and II, they have only refined the statutory regime that governs certificate proceedings. The executive has not been subordinated to criminal law principles, nor have the governing legislative provisions of the security certificate system been ruled altogether unconstitutional. Instead, courts have used a bare minimum of procedural safeguards to better level the playing field, leaving it up to the government, special advocates, and persons facing deportation to work within an otherwise unaltered system.
The true impact of Charkaoui I and II accordingly lies in how the checks and balances already embedded within the certificate system itself have, and have not, been altered. Re Charkaoui offers a timely illustration - at the level of day-to-day proceedings - of how deeply the principles of criminal law have filtered through this system, affecting the interplay of national security and procedural fairness.

\section{Setting the Stage: Security Certificates and Disclosure}

Security certificates are issued under the joint powers of the Minister of Public Safety and the Minister of Citizenship and Immigration ("the ministers") ${ }^{8}$ against persons the ministers allege are inadmissible to Canada on the grounds of national security, the violation of international human rights, serious criminality, or organized crime. ${ }^{9}$ Once issued, a certificate authorizes the detention of a non-citizen, the named person, pending a review of the reasonableness of the certificate by a Federal Court judge. If a certificate is ultimately found to be reasonable, it stands as conclusive proof that the person named in it is inadmissible; it effectively becomes a removal order. ${ }^{10}$

Even though activities which may trigger a security certificate are also elements of a number of criminal offences, named persons are denied many procedural protections associated with criminal proceedings. For instance, the IRPA requires judges to conduct certificate and detention review proceedings "as informally and expeditiously as the circumstances and considerations of fairness and natural justice permit," to receive into evidence anything that, in their opinion, "is reliable and appropriate, even if it is inadmissible in a court of law," and to base their decisions on that evidence. ${ }^{11}$ At the request of the ministers, a judge is required to hear evidence in the absence of the public, the person named in a certificate, and his counsel, if the judge is satisfied that the disclosure of such evidence could be injurious to national security or the safety of any person. The judge also must maintain the confidentiality of the evidence for so long as its disclosure would be so injurious. ${ }^{12}$ 
While judges are required to provide named persons with a summary of the evidence heard in private, the IRPA allows judges to make decisions on the basis of evidence that named persons have not heard or responded to, as well as evidence which, for whatever reason, has not been summarized and provided to them. ${ }^{13}$

In criminal proceedings, by contrast, the accused is generally entitled to receive any and all relevant information in the possession of Crown prosecutors and the police. ${ }^{14}$ It does not matter if the information is favourable to the accused or if prosecutors intend to submit it as evidence. So long as the information is relevant to an accused's ability to know the case against him and to make full answer and defence, the government is obligated to disclose it.

Sometimes, such as in criminal cases touching upon national security, the government's duty of disclosure may be narrowed. For instance, under section 38 of the Canada Evidence $A c t^{15}$ the Attorney General may file motions for the non-disclosure of information for reasons of international relations, national defence, or national security. As in certificate proceedings, judges consider these motions in the absence of the accused and the public, and on the basis of information that might never be disclosed to the accused. ${ }^{16}$ Unlike in certificate proceedings, however, information that is kept secret under section 38 may not be submitted as evidence against the accused. In other words, any information that is submitted as evidence must be shared with the accused.

To further balance secrecy and disclosure, the Evidence Act allows the accused to apply to the Federal Court for an order requiring full or partial disclosure of information relevant to his defence. ${ }^{17}$ The judge must confirm the prohibition on disclosure - even of relevant information - if she finds that disclosure would be injurious to international relations, national defence, or national security, and also finds that the public's interest in non-disclosure is outweighed by its interest in disclosure. ${ }^{18}$ Under the Evidence Act, then, judges are authorized to balance the public's (and state's) interest in non-disclosure with the public's (and accused's) interest in disclosure. If the value of non-disclosure outweighs the value of disclosure, judges are authorized to consider ordering partial disclosure. ${ }^{19}$ The accused may thus be provided with redacted copies or summaries of relevant information.

\section{Tipping the Scales: National Security and Procedural Fairness}

In 2008, the Supreme Court moved to infuse elements of criminal law principles into certificate proceedings. In Charkaoui I, the Court found that certificate proceedings and criminal proceedings are analogous on the basis of the kind and degree of their adverse impacts upon the life, liberty, and security of affected persons. As such, the Court found it appropriate to apply principles of fundamental justice developed in the context of the criminal law to certificate proceedings. ${ }^{20}$ Applying these principles, the Court found that named persons are entitled to a fair hearing, which includes the right to know the case against them, to respond to that case, and to have decisions made on the basis of the facts and the law. ${ }^{21}$ It ruled that excluding named persons and their legal counsel from significant portions of certificate proceedings is inconsistent with the right to a fair hearing and, consequently, with section 7 of the Canadian Charter of Rights and Freedoms. ${ }^{22}$

In response to this decision, Parliament amended the IRPA to authorize security-cleared "special advocates" to represent named persons during secret proceedings, to access classified evidence, and to challenge that evidence as well as the government's applications for non-disclosure. ${ }^{23}$ The role of a special advocate is similar to that of a lawyer: improving the level of adversarial challenge during secret hearings. Of course, the value of disclosure is only partially realized, as neither named persons nor their counsel are permitted, absent judicial authorization, to personally access confidential evidence or to converse with special advocates once the latter has seen the evidence. ${ }^{24}$ IRPA also does not expressly empower special advocates to subpoena documents or witnesses; they may not demand disclosure of any information that is not submitted as evidence by the ministers.

Special advocates' inability to subpoena 
documents and witnesses, or to communicate freely with named persons, are well-documented flaws in this system. ${ }^{25}$ Some of these flaws were remedied in Charkaoui II, when the Supreme Court ruled that the government is generally obligated to disclose "all information in its possession regarding the person named in a security certificate." 26 This duty was not extended to require the disclosure of information directly to named persons, as in criminal proceedings. The Court only imposed upon the government a duty to disclose information to reviewing judges and, by implication, to special advocates. ${ }^{27}$ On receiving the information, reviewing judges become responsible for deciding what may be directly disclosed to named persons. ${ }^{28}$

This ruling helped harmonize certificate provisions with section 38 of the Evidence Act. Decisions on what information is relevant or can safely be disclosed are no longer left to the discretion of the ministers. As in criminal proceedings, all relevant information must be submitted to reviewing judges and special advocates, remedying to some degree special advocates' inability to subpoena documents. Reviewing judges, with the benefit of arguments from the ministers and special advocates, are then responsible for deciding what information may be disclosed to named persons. In cases where information cannot safely be disclosed to named persons, judges are able to order partial disclosure in the form of summaries. Of course, in such instances, judges may base their decisions on evidence not directly disclosed to named persons; in the criminal context this cannot happen. Nonetheless, the displacement of discretion about disclosure from the ministers to courts has enabled reviewing judges and special advocates to work with more complete information.

\section{The Ministers Strike Back: Discretion, Disclosure, and Re Charkaoui}

Analogies between the certificate provisions and section 38 of the Evidence Act raise an important question: what criteria should judges apply to decide matters of disclosure? The Evi- dence Act allows judges to balance values of non-disclosure with values of disclosure in order to strike a justifiable compromise in criminal proceedings. By contrast, the IRPA states in no uncertain terms:

[T]he judge shall ensure the confidentiality of information and other evidence provided by the Minister if, in the judge's opinion, its disclosure would be injurious to national security or endanger the safety of any person. ${ }^{29}$

The only consideration judges are to apply during certificate proceedings is whether disclosure would be injurious to national security or would endanger personal safety. In deciding on disclosure, they are not allowed to consider the interests of named persons or the public. Judges may not, in other words, balance values of disclosure with values of non-disclosure.

The Supreme Court did not change this feature of the law in Charkaoui II. In fact, it said almost nothing about the criteria that should govern disclosure. All the Court said was:

[C]onfidentiality requirements related to public safety and state interests will place limits on how this duty [of disclosure] is discharged. In short, the judge must filter the evidence he or she has verified and determine the limits of the access to which the named person will be entitled at each step of the process, both during the review of the validity of the certificate and at the detention review stage. ${ }^{30}$

Presumably, the Court expected judges to make this determination consistently with provisions of the IRPA that require decisions about the disclosure of information to be made only after judges consider the ministers' and special advocates' positions on the issue. ${ }^{31}$ If a judge ultimately finds that certain information can be safely disclosed, she shall make an order to that effect. However, if she finds that the information cannot be safely disclosed, named persons are not entitled to access this information, no matter how pressing their or the public's interest in disclosure may be. However, they are still entitled to receive summaries of the information. ${ }^{32}$

In the months following Charkaoui II, the government, special advocates, and named persons competed to influence the trajectory of 
disclosure. Immediately after the Charkaoui II decision, Mr. Charkaoui's counsel and special advocates applied to the Federal Court for an order requiring the government to disclose directly to Mr. Charkaoui considerable volumes of information. Notwithstanding the ministers' arguments, the reviewing judge, Justice Tremblay-Lamer, found that certain evidence could be disclosed to Mr. Charkaoui without compromising national security or the safety of any person. She proceeded to order the ministers to disclose this evidence directly to Mr. Charkaoui and also to provide, during closed hearings, original copies of the Canadian Security Intelligence Service's (CSIS) operational notes pertaining to this evidence. Justice Tremblay-Lamer indicated that she would give Mr. Charkaoui summaries of these originals and associated information, including some details the ministers had insisted could not be safely disclosed. ${ }^{33}$

Unwilling to let any of this information be disclosed, the ministers invoked section 83(1)(j) of the IRPA to withdraw the disputed evidence. The section reads:

[T] he judge shall not base a decision on information or other evidence provided by the Minister, and shall return it to the Minister, if the judge determines that it is not relevant or if the Minister withdraws it.

As a result of this withdrawal of evidence, the court lacked the authority to require the disclosure of the contested information to $\mathrm{Mr}$. Charkaoui, either directly or in summary form. The withdrawal of the evidence also meant that the ministers did not have sufficient evidence to support the reasonableness of the certificate. Justice Tremblay-Lamer ruled the security certificate ultra vires the legislative authority of the ministers, since the IRPA provides that no certificate may be issued without the submission to a Federal Court judge of evidence supporting the ministers' allegations. ${ }^{34}$ The withdrawal of any such evidence precludes a meaningful review of the reasonableness of the certificate. Having found Mr. Charkaoui's certificate to be illegal, Justice Tremblay-Lamer quashed it and set him free. ${ }^{35}$

Why would the ministers jeopardize the validity of the certificate, just to avoid disclosing information to security-cleared officials who are obligated to maintain its confidentiality? One obvious reason is that they hoped to preserve the confidentiality of any sensitive information that was going to be directly disclosed to $\mathrm{Mr}$. Charkaoui. More importantly though, the ministers believed that Justice Tremblay-Lamer had ordered the disclosure of information on the erroneous grounds that Mr. Charkaoui's and the public's interest in disclosure outweighed the government's interest in secrecy. No formal criteria on this issue had been established in or subsequent to Charkaoui II. The ministers wanted to force a decision on the reasonableness of the certificate, so that they could then submit certified questions on the applicable criteria for the Federal Court of Appeal's consideration.

The ministers' questions related to the criteria reviewing judges should use when they decide whether the disclosure of information would be injurious to national security or the safety of any person. In particular, they wanted to know, first, how judges are to balance the inherent tension between their duty to safeguard the confidentiality of sensitive information and their duty to protect named persons' right to be informed of the case against them through the provision of summaries. Second, the ministers wanted to know what consideration should be given to the fact that special advocates may challenge the relevance, reliability, sufficiency, and weight of evidence that is not directly disclosed to named persons. ${ }^{36}$

\section{A Serious Question of General Importance?}

A defining feature of certificate proceedings is that they are to be conducted as "informally and expeditiously as the circumstances and considerations of fairness and natural justice permit." ${ }^{37}$ In order to expedite the certificate and detention review process, Parliament chose to provide both named persons and the ministers with a limited right of appeal on certificatebased matters. Section 79 of the IRPA states:

An appeal from the determination [of the reasonableness of a certificate] may be made to 
the Federal Court of Appeal only if the judge certifies that a serious question of general importance is involved and states the question. However, no appeal may be made from an interlocutory decision in the proceeding.

The Federal Court has in other contexts established criteria for deciding what constitutes a "serious question of general importance." ${ }^{8}$ The criteria are: that the question transcend the interests of the parties to that case; that its (non-) resolution have important consequences for outside parties; that it be dispositive of the appeal; and that the question arise from the facts of the case. This last criterion has been specified to mean that the question must arise "from the issues in the case and not from the judge's reasons." ${ }^{39}$ The question, therefore, must be one of law or mixed law and fact, and not one of pure fact.

Mr. Charkaoui argued that the ministers' questions failed the section 79 IRPA threshold because they were questions of fact that did not touch upon issues of "general importance." Indeed, in Suresh v. Canada (Minister of Citizenship and Immigration) ${ }^{41}$ the Supreme Court found that "the determination of what constitutes a 'danger to the security of Canada' is highly fact-based." ${ }^{2}$ Generally, judges' conclusions on this matter centre on the nature of the evidence presented to them, viewed in proper factual context; ${ }^{43}$ they do not decide the matter on the basis of abstract legal reasoning. In the case at hand, Mr. Charkaoui argued, Justice Tremblay-Lamer had simply found that the disclosure of certain information would, in fact, not be injurious to national security or the safety of any person. Mr. Charkaoui also took the position that the general, legal question of what criteria should be used when making these types of factual determinations had already been sufficiently answered in Charkaoui II.

Mr. Charkaoui's special advocates echoed these points, arguing that that the reviewing judge did not balance the values of secrecy and disclosure, but instead "reconciled" them. ${ }^{44}$ If any such balancing had taken place, the special advocates conceded, the question would have been one of mixed law and fact. Justice Tremblay-Lamer had simply ordered the disclosure of information that she expressly decided would not compromise national security or the safety of any person. This was consistent with Charkaoui II and prior Federal Court jurisprudence. ${ }^{45}$ The issue seemed solely to be whether Justice Tremblay-Lamer had made a factually correct determination, and not whether she had engaged in an improper balancing act.

Justice Tremblay-Lamer ultimately found that the ministers' questions were not serious or of general importance. Rather, the questions were part of an attempt to garner a second opinion on whether the disclosure of certain information would be injurious to national security or the safety of any person. ${ }^{46}$ If the ministers had attained a favourable ruling on this question, they would have been able to re-submit the withdrawn evidence without Mr. Charkaoui having the benefit of expanded disclosure.

\section{Just the Facts: Federal Court Judges on the Question of Disclosure}

Can it be said that these were not serious questions of general importance? It is fair to say that Charkaoui II did not clarify the criteria judges should use in determining whether to order the disclosure of information to named persons. The Supreme Court left the matter to be handled by Federal Court judges applying the terms of the IRPA. However, it is also fair to say that the terms of the legislation suffice to guide reviewing judges in their approach to the scope of Charkaoui II disclosure. Again, section 83(1)(d) of the IRPA states:

[J]udges shall ensure the confidentiality of information and other evidence provided by the Minister if, in the judge's opinion, its disclosure would be injurious to national security or endanger the safety of any person.

Section 83(1)(e) also clearly states:

[T]hroughout the proceeding, the judge shall ensure that the permanent resident or foreign national is provided with a summary of information and other evidence that enables them to be reasonably informed of the case made by the Minister in the proceeding but that does not include anything that, in the judge's opin- 
ion, would be injurious to national security or endanger the safety of any person if disclosed.

There is no ambiguity here. Judges are simply not authorized to order the disclosure of information if they determine that a named person's or the public's interest in disclosure outweighs the government's interest in secrecy. It is hard to imagine the Federal Court of Appeal saying otherwise, had the ministers' questions been certified. If Justice Tremblay-Lamer did engage in this kind of reasoning when she ordered the release of certain information, certainly a redetermination of the facts would be in order. If reviewing judges consistently engaged in this kind of reasoning, a serious question of general importance might also be raised. Unfortunately for the ministers, Parliament only included a limited right of appeal in Division 9 of the IRPA. ${ }^{47}$ Disagreements with factual determinations or a mere suspicion that an error of law has occurred do not form the basis of a right to appeal.

On closer inspection, there is little to suggest that reviewing judges have consistently applied faulty criteria in determining the scope of Charkaoui II disclosure. Post-Charkaoui II jurisprudence certainly demonstrates an expansive ministerial obligation to disclose sensitive information to reviewing judges and special advocates - quite correctly, given the Supreme Court's ruling to this effect. In the fall of 2008, for instance, the Federal Court required CSIS and the ministers to "file all information and intelligence related to Mohamed Harkat including but not limited to drafts, diagrams, recordings and photographs in CSIS' possession or holdings." 48 The government complied, disclosing approximately 2,000 documents (containing at least 8,000 pages) to the court and to Mr. Harkat's special advocates. ${ }^{49}$ The government's compliance was to be expected, as the Federal Court's order followed the Supreme Court's ruling that the government is obligated to disclose to courts and special advocates "all information in its possession regarding persons named in a certificate." 50

Still, the precise scope of Charkaoui II disclosure is hotly contested in court. In the case of Mr. Harkat, the government redacted signifi- cant portions of the documents it was ordered to disclose to Mr. Harkat's special advocates, based on its assessment of relevance as well as privilege. ${ }^{51}$ In March 2009, the Federal Court lifted most of the redactions in 67 contested documents, after it found that disclosing this information to special advocates would not be injurious to national security or endanger the safety of any person..$^{52}$

At the opposite end of the spectrum, the Federal Court has refused to fully apply criminal law principles in Charkaoui II disclosure proceedings. In the criminal context, the government generally must disclose to the accused any and all information in its possession that is relevant to the defence. This comparatively low threshold of relevance is premised on the principle that the accused's right to a fair hearing requires the opportunity to make full answer and defence to charges against him. Although the Supreme Court expressly identified this principle in Charkaoui I and II, reviewing judges have interpreted Charkaoui II as entitling special advocates only to such information as is "necessary to examine and verify the accuracy of the information submitted" to court. ${ }^{53}$

Generally speaking, when reviewing judges have expressly applied criminal law principles, they have done so in order to narrow the scope of Charkaoui II disclosure. In one of the Harkat proceedings, the Federal Court denied special advocates' request for access to the employment records of a former CSIS officer who had testified against Mr. Harkat. Relying on R. v. O'Connor, ${ }^{54}$ special advocates had argued that these records were likely to be relevant to the proceeding and, since they were obligated to maintain the confidentiality of any disclosed information, third parties in possession of this information had no reasonable expectation of privacy. ${ }^{55}$ The ministers responded that Charkaoui II renders criminal law principles applicable to certificate proceedings and that relevant common-law rules of privilege therefore also apply. The Federal Court agreed with the ministers, holding that the employment records were not necessary to verify the accuracy of available evidence. ${ }^{56}$

In a similar motion, special advocates for Mr. Harkat sought an order compelling the 
ministers to produce for cross-examination covert human intelligence sources that had provided information about Mr. Harkat to CSIS. ${ }^{57}$ The special advocates argued that cross-examination was necessary to test the credibility of the information and to corroborate elements of Mr. Harkat's testimony. Invoking the Supreme Court's ruling that criminal law principles are applicable to both certificate proceedings and civilian intelligence activities, the ministers responded that police informer privilege, a recognized exemption from the duty to disclose in criminal proceedings, ${ }^{58}$ is applicable to certificate proceedings and to sources recruited by civilian intelligence agencies. The Federal Court recognized the merit of both sides, ruling that disclosure of a covert human intelligence source requires proof that disclosure is necessary to "prevent a flagrant denial of procedural fairness which would bring the administration of justice into disrepute." ${ }^{\prime 9}$ It further held that the fact that certificate proceedings are closed does not, by itself, override common-law privilege or the policy on which it is based. ${ }^{60}$ This judgment highlights how criminal law principles can be effectively used to limit the government's obligation to disclose.

\section{Conclusion: The Constitutional Dimensions of Disclosure}

The concept of balance structures much of our thinking about the human-rights dimensions of national security law and policy. Legislators, lawyers, judges, academics, and the public may have different conceptions of the proper balance between national security and human rights, but all agree that the concept itself should help frame the debate. Indeed, at an abstract level, the nature and rhetorical use of the concept of national security presupposes a balance between the preservation of existing governmental institutions and respect for rights and the rule of law. This is because in Canada, the protection of national security is inseparable from the protection of institutions of democrat$i c$ governance. One cannot speak meaningfully about national security without engaging with conceptions of balance and proportionality.
On another level, balance refers also to the checks and balances characteristic of our constitutional order. Among these are the imperfect ways in which we have separated the functions of the legislatures, the executive, and the judiciary. The executive has been the dominant branch in structuring our national security law and policy, until recently without meaningful parliamentary and judicial review. Led by the Supreme Court, the judiciary has begun to reassert balance, reviewing law, policy, and associated practices for consistency with core constitutional values. This movement has been echoed in some measure by the work of parliamentary committees and in the government's legislative response to judicial rulings and international criticisms. ${ }^{61}$ We are beginning to see the reassertion of balance, a move towards parity in the influence exerted by our three branches of government in the national security field.

Re Charkaoui affords us a glimpse of this process at work, and it also reveals the anxieties that accompany shifts in balances of power. Given the indelible influence of the notion of balance on our thinking, it comes as no surprise that a particular kind of balance should have been the central issue of the case. However, the philosophical, political, and ideological contours of this larger debate find no expression in the legal issues at hand. Contrary to the government's claims, reviewing judges have not generally (or, on the evidence, singularly) exceeded their authority by balancing the value of national security with concern for improper or invalid counter-values. They have restricted their determinations about issues of disclosure to criteria that are explicit in legislation and were illuminated by Charkaoui II.

Given the Federal Court's historic reluctance to infuse criminal law principles into certificate proceedings, the government may be surprised at how quickly and forcefully the tides have changed. The executive branch certainly needs to adapt to a different, less hospitable climate. However, there are no constitutional grounds for challenging the current trajectory of judicial decision-making on the scope of Charkaoui II disclosure. The balance that emerges from the recent spate of security certificate cases is, if 
anything, an overdue endorsement of core values of Canadian constitutionalism.

\section{Notes}

* PhD Candidate, Osgoode Hall Law School.

1 Sweeping changes to criminal law were initiated through the Anti-terrorism Act, S.C. 2001, c. 41.

2 Certificate provisions are governed by Division 9 of the Immigration and Refugee Protection Act, S.C. 2001, c. 27 [IRPA].

3 Canada (Minister of Employment and Immigration) v. Chiarelli, 1992 CanLII 87 (S.C.C.), [1992] 1 S.C.R. 711.

4 Charkaoui v. Canada (Citizenship and Immigration), 2007 SCC 9, [2007] 1 S.C.R. 350 (CanLII) [Charkaoui I].

5 An Act to amend the Immigration and Refugee Protection Act (certificate and special advocate) and to make a consequential amendment to another Act, S.C. 2008, c. 3, ss. 83-87, amending Immigration and Refugee Protection Act, S.C. 2001, c. 27, Part 1, Division 9.

6 Charkaoui v. Canada (Citizenship and Immigration), 2008 SCC 38, [2008] 2 S.C.R. 326 (CanLII) [Charkaoui II].

72009 FC 1030 (CanLII) [Re Charkaoui].

8 IRPA, supra note 2, ss. 4, 77(1). The Minister of Public Safety was formerly styled the Minister of Public Safety and Emergency Preparedness; the Minister of Citizenship and Immigration is now styled the Minister of Citizenship, Immigration and Multiculturalism.

$9 \quad$ Ibid., ss. 4(2)(c), 77(1).

10 Ibid., s. 80.

11 Ibid., s. 83(1)(a), (h).

12 Ibid., s. 83(1)(c)-(d).

13 Ibid., s. 83(1)(e), (i).

14 R. v. Stinchcombe, 1991 CanLII 45 (S.C.C.), [1991] 3 S.C.R. 326; R. v. Egger, 1993 CanLII 98 (S.C.C.), [1993] 2 S.C.R. 451; R. v. O’Connor, 1995 CanLII 51 (S.C.C.), [1995] 4 S.C.R. 411; R. v. La, 1997 CanLII 309 (S.C.C.), [1997] 2 S.C.R. 680.

15 R.S.C. 1985, c. C-5, 2001, c. 41 [CEA], as amended by Anti-terrorism Act, S.C. 2001, c. 41, s. 43. The constitutionality of this provision was upheld in Canada (Attorney General) v. Khawaja, 2007 FCA 388, [2008] 4 F.C.R. 3 (CanLII), leave to appeal to S.C.C. refused 32397 (3 April 2008), 166 C.R.R. (2d) 375.

16 CEA, ibid., s. 38.04(5)(a)-(d).

17 Ibid., s. 38.04(2)(c).

18 Ibid., s. 38.06.

19 Such a ruling was made in Khadr v. Canada (Attorney General), 2008 FC 549, 329 F.T.R. 80
(CanLII).

20 The principled basis for this application was established in Dehghani v. Canada (Minister of Employment and Immigration), 1993 CanLII 128 (S.C.C.), [1993] 1 S.C.R. 1053 at 1077. For academic commentary on this point, see Hamish Stewart, "Is Indefinite Detention of Terrorist Suspects Really Constitutional?”(2005) 54 University of New Brunswick Law Journal 235.

21 Charkaoui I, supra note 4 at para. 29.

22 The Constitution Act, 1982, being Schedule B to the Canada Act, 1982 (U.K.), 1982, c. 11.

23 IRPA, supra note 2, ss. 85.1 (1)-(2), 85.2.

24 Ibid., ss. 85.4(2)-(3), 85.5.

25 For criticisms of the Canadian model, see Craig Forcese and Lorne Waldman, Seeking Justice in an Unfair Process: Lessons from Canada, the United Kingdom, and New Zealand on the Use of "Special Advocates" in National Security Proceedings (Ottawa: University of Ottawa, 2007), online: University of Ottawa <http://aix1.uottawa. $\mathrm{ca} / \sim$ cforcese/other/sastudy.pdf $>$. For criticisms of the United Kingdom model upon which the Canadian model was premised, see: United Kingdom, House of Commons and House of Lords, Report of the Joint Committee on Human Rights, Review of Counter-terrorism Powers (July 2004) at para. 40; United Kingdom, House of Commons, Report of the Constitutional Affairs Committee, The operation of the Special Immigration Appeals Commission (SIAC) and the use of Special Advocates (March 2005).

26 Charkaoui II, supra note 6 at para. 2.

27 Ibid.; see IRPA, supra note 2, s. 85.4(1).

28 Charkaoui II, supra note 6 at para. 2.

29 IRPA, supra note 2, s. 83(1)(d).

30 Charkaoui II, supra note 6 at para. 63.

31 IRPA, supra note 2, ss. 83(1), 85.1(2)(a).

32 Ibid., s. 83(1)(e).

33 Re Charkaoui, supra note 7, Appendix "A".

34 IRPA, supra note 2, s. 83(1)(j).

35 Re Charkaoui, supra note 7 at paras. 23-28.

36 Ibid. at para. 49.

37 IRPA, supra note 2, s. 83(1)(a).

38 Varela v. Canada (Citizenship and Immigration), 2009 FCA 145, 391 N.R. 366 (CanLII) [Varela]; Zazai v. Canada (Minister of Citizenship and Immigration), 2004 FCA 89, 247 F.T.R. 320 (CanLII); Gallardo v. Canada (Minister of Citizenship and Immigration), 2003 FCT 45, 230 F.T.R. 110 (CanLII); Bath v. Canada (Minister of Citizenship and Immigration), 1999 CanLII 8549 (F.C.), (1999) 90 A.C.W.S. (3d) 461 (F.C.T.D.); Canada (Minister of Citizenship and Immigration) v. Liyanagamage (1994), 176 N.R. 4 (F.C.A.); Baldizon-Ortegaray v. 
Canada (Minister of Employment and Immigration) (1993), 20 Imm. L.R. (2d) 307, 64 F.T.R. 190 (F.C.T.D.).

39 Varela, supra note 38 at para. 29.

$40 \quad$ Re Charkaoui, supra note 7 at para. 57.

412002 SCC 1, [2002] 1 S.C.R. 3 (CanLII).

42 Ibid. at para. 85.

43 Re Harkat, 2005 FC 393, 261 F.T.R. 52 at paras. 81-89 (CanLII); Re Almrei, 2009 FC 322, 342

F.T.R. 11 at paras. 54-59 (CanLII).

44 Re Charkaoui, supra note 7 at para. 62.

45 Re Harkat, supra note 43 at para. 89.

46 Re Charkaoui, supra note 7 at para. 92.

47 IRPA, supra note 2, s. 82.3.

48 Re Harkat, 2009 FC 340, 339 F.T.R. 129 at para. 4 (CanLII).

49 Ibid. at para. 7.

50 Charkaoui II, supra note 6 at para. 2.

51 Re Harkat, supra note 48 at para. 7.

52 Ibid. at para. 9.

53 Re Harkat, 2009 FC 203, 339 F.T.R. 60 at para. 12 (CanLII) (emphasis added).

54 R. v. O'Connor, supra note 15.

55 Re Harkat, supra note 53 at para. 5.

56 Ibid. at paras. 11-12.

57 Re Harkat, 2009 FC 204, 306 D.L.R. (4 $\left.{ }^{\text {th }}\right) 269$ (CanLII).

58 R. v. Leipert, 1997 CanLII 367 (S.C.C.), [1997] 1 S.C.R. 281; Bisaillon v. Keable, 1983 CanLII 26 (S.C.C.), [1983] 2 S.C.R. 60; Canada (Solicitor General) v. Royal Commission (Health Records), 1981 CanLII 33 (S.C.C.), [1981] 2 S.C.R. 494; Marks v. Beyfus (1890), 25 Q.B.D. 494 (C.A.).

59 Re Harkat, supra note 57 at para. 35.

60 Ibid. at para. 55.

61 House of Commons, Report of the Standing Committee on Public Safety and National Security, Rights, Limits, Security: A Comprehensive Review of the Anti-terrorism Act and Related Issues (March 2007); Senate, Report of the Special Senate Committee on the Anti-terrorism Act, Fundamental Justice in Extraordinary Times (February 2007); House of Commons, Report of the Standing Committee on Citizenship and Immigration, Detention Centres and Security Certificates (April 2007). 